\title{
Telbivudine versus Lamivudine in Patients with Chronic Hepatitis B
}

\author{
Ching-Lung Lai, M.D., Edward Gane, M.D., Yun-Fan Liaw, M.D., \\ Chao-Wei Hsu, M.D., Satawat Thongsawat, M.D., Yuming Wang, M.D., \\ Yagang Chen, M.D., E. Jenny Heathcote, M.D., Jens Rasenack, M.D., \\ Natalie Bzowej, M.D., Ph.D., Nikolai V. Naoumov, M.D., \\ Adrian M. Di Bisceglie, M.D., Stefan Zeuzem, M.D., \\ Young Myoung Moon, M.D., Zachary Goodman, M.D., \\ George Chao, Ph.D., Barbara Fielman Constance, R.N., \\ and Nathaniel A. Brown, M.D., for the Globe Study Group*
}

\section{A BSTRACT}

From the University Department of Medicine, Queen Mary Hospital, Hong Kong (C.-L.L.); Middlemore Hospital, Auckland, New Zealand (E.G.); Chang Gung Memorial Hospital, Chang Gung University College of Medicine, Taipei, Taiwan (Y.-F.L., C.-W.H.); Chiang Mai University, Chiang Mai, Thailand (S.T.); Xi Nan Hospital, Third Military Medical University, Chongqing, China (Y.W.); First Affiliated Hospital, Zhejiang University, Hangzhou, China (Y.C.); University of Toronto, Toronto (E.J.H.); Albert Ludwigs University, Freiburg, Germany (J.R.); Sutter Health, San Francisco (N.B.); University College, London (N.V.N.); Saint Louis University, St. Louis (A.M.D.); Saarland University Hospital, Homburg, Germany (S.Z.); Yonsei University College of Medicine, Seoul, Korea (Y.M.M.); the Armed Forces Institute of Pathology, Washington, DC (Z.G.); and Idenix Pharmaceuticals, Cambridge, MA (G.C., B.F.C., N.A.B.). Address reprint requests to $\mathrm{Dr}$. Lai at the University Department of Medicine, Queen Mary Hospital, Hong Kong, China, or at hrmelcl@hkucc.hku.hk.

*The other investigators in the Globe Study Group are listed in the Appendix.

N Engl J Med 2007;357:2576-88.

Copyright $(2007$ Massachusetts Medical Society.

\section{BACKGROUN D}

Reducing hepatitis B virus (HBV) replication to minimal levels is emerging as a key therapeutic goal for chronic hepatitis B.

\section{METHODS}

In this double-blind, phase 3 trial, 1370 patients with chronic hepatitis B were randomly assigned to receive $600 \mathrm{mg}$ of telbivudine or $100 \mathrm{mg}$ of lamivudine once daily. The primary efficacy end point was noninferiority of telbivudine to lamivudine for therapeutic response (i.e., a reduction in serum HBV DNA levels to fewer than $5 \log _{10}$ copies per milliliter, along with loss of hepatitis B e antigen [HBeAg] or normalization of alanine aminotransferase levels). Secondary efficacy measures included histologic response, changes in serum HBV DNA levels, and HBeAg responses.

\section{RESULTS}

At week 52, a significantly higher proportion of HBeAg-positive patients receiving telbivudine than of those receiving lamivudine had a therapeutic response $(75.3 \%$ vs. $67.0 \%, \mathrm{P}=0.005)$ or a histologic response ( $64.7 \%$ vs. $56.3 \%, \mathrm{P}=0.01)$; telbivudine also was not inferior to lamivudine for these end points in HBeAg-negative patients. In HBeAg-positive and HBeAg-negative patients, telbivudine was superior to lamivudine with respect to the mean reduction in the number of copies of HBV DNA from baseline, the proportion of patients with a reduction in HBV DNA to levels undetectable by polymerase-chain-reaction assay, and development of resistance to the drug. Elevated creatine kinase levels were more common in patients who received telbivudine, whereas elevated alanine aminotransferase and aspartate aminotransferase levels were more common in those who received lamivudine.

\section{CONCLUSIONS}

Among patients with HBeAg-positive chronic hepatitis B, the rates of therapeutic and histologic response at 1 year were significantly higher in patients treated with telbivudine than in patients treated with lamivudine. In both the HBeAg-negative and the HBeAg-positive groups, telbivudine demonstrated greater HBV DNA suppression with less resistance than did lamivudine. (ClinicalTrials.gov number, NCT00057265.) 
F OR THE APPROXIMATELY 400 MILLION people with chronic hepatitis $\mathrm{B}$ virus (HBV) infection, the risk of progression to end-stage complications such as cirrhosis and hepatocellular carcinoma has been correlated with persistent HBV replication, as reflected by serum HBV DNA levels. ${ }^{1}$ Correspondingly, prolonged suppression of HBV replication with antiviral therapy has been linked to reduced risks of end-stage disease manifestations, a finding that underscores the importance of long-lasting HBV suppression as a primary treatment goal. ${ }^{2-9}$

Multiple types of interferon, lamivudine, adefovir dipivoxil, entecavir, and telbivudine have been approved for the treatment of chronic hepatitis $B$. These agents vary with respect to antiviral and clinical efficacy, resistance profiles, and tolerability and safety. ${ }^{10}$ For long-term disease management, the clinical challenge is to determine how to use available agents most effectively to obtain consistent, profound, and long-lasting HBV suppression with good safety and convenience in a wide variety of health care settings.

Telbivudine ( $\beta$ - $\mathrm{L}-2^{\prime}$-deoxythymidine) is an orally bioavailable L-nucleoside with potent and specific anti-HBV activity. ${ }^{11}$ In preclinical toxicologic testing, telbivudine had no mutagenic or carcinogenic effects and no appreciable embryonic or fetal toxic effects - findings that are particularly relevant for men and women in their reproductive years. ${ }^{12}$ In initial clinical trials, treatment with telbivudine led to reductions in serum HBV DNA levels that were greater than those observed with lamivudine, and resistance to telbivudine developed less frequently than did resistance to lamivudine. ${ }^{13,14}$

The present international phase 3 trial, designated Globe, compared the safety and efficacy of treatment with telbivudine with that of lamivudine, the most widely prescribed anti-hepatitis $B$ agent worldwide, in patients with chronic hepatitis B. Patients with hepatitis B e antigen (HBeAg)positive chronic hepatitis $\mathrm{B}$ and those with $\mathrm{HBeAg}$ negative chronic hepatitis $B$ were evaluated to assess differences in therapeutic outcomes that may arise as a result of well-recognized differences in disease characteristics. ${ }^{10,15-17}$ Associations between early suppression of HBV replication and subsequent efficacy and resistance outcomes were assessed. ${ }^{14,18,19}$

\section{METHODS}

\section{PATIENTS}

Men and women between 16 and 70 years of age who had HBeAg-positive or HBeAg-negative chronic hepatitis B were eligible to participate in the study. The study investigators recruited the patients from March 2003 until April 2004 after a review of medical records and the completion of screening procedures to establish their eligibility for the trial. Chronic hepatitis B was defined by detectable serum hepatitis B surface antigen (HBsAg), a serum alanine aminotransferase level 1.3 to 10.0 times the upper limit of normal, a serum HBV DNA level greater than $6 \log _{10}$ copies per milliliter, and compatible pretreatment liver histologic findings.

Exclusion criteria included coinfection with hepatitis $\mathrm{C}$, hepatitis $\mathrm{D}$, or the human immunodeficiency virus; evidence of hepatic decompensation, pancreatitis, or hepatocellular carcinoma; previous treatment for hepatitis B with nucleoside or nucleotide analogues or both; treatment with interferon or other immunomodulators within the previous 12 months; other forms of liver disease; a serum creatinine level greater than 1.5 mg per deciliter (133 $\mu \mathrm{mol}$ per liter); a serum amylase or lipase level greater than 1.5 times the upper limit of normal; a prothrombin time prolonged by more than 3 seconds; a serum albumin level less than $3.3 \mathrm{~g}$ per deciliter; and a bilirubin level greater than $2.0 \mathrm{mg}$ per deciliter (34 $\mu \mathrm{mol}$ per liter). Eligible patients with a serum alpha fetoprotein level greater than $50 \mathrm{ng}$ per milliliter required exclusion of underlying hepatocellular carcinoma.

\section{STUDY DESIGN}

This randomized, double-blind, active agent-controlled trial was conducted at 112 academic centers in 20 countries. Eligible subjects were randomly assigned centrally in a 1:1 ratio to receive $600 \mathrm{mg}$ of telbivudine or $100 \mathrm{mg}$ of lamivudine once daily as oral tablets. Treatment assignments were stratified according to HBeAg status (positive or negative) and serum alanine aminotransferase level ( $>2.5$ or $\leq 2.5$ times the upper limit of normal). Within each stratum, patients were randomly assigned in block sizes of four. Study drugs were sup- 
plied in bottles containing telbivudine (Idenix Pharmaceuticals) or overencapsulated lamivudine tablets (GlaxoSmithKline). Primary data analyses were specified for a 52-week treatment period, with the cohort continuing into a second year for longer-term assessments.

Patient histories were obtained, physical examinations were conducted, and venipuncture samples for laboratory assessments were obtained at screening, at baseline, and at weeks $2,4,8,12,16$, 24, 32, 40, 48, and 52. Standardized tests were performed centrally by Quintiles Transnational. Serum HBV DNA levels were quantified by COBAS Amplicor HBV Monitor (Roche Molecular Systems), with a detection limit of 300 copies per milliliter. Serum samples obtained at screening, baseline, and week 2 were prediluted at a 1:1000 ratio to ensure that HBV DNA assessments were within the assay's linear range. Liver-biopsy specimens, collected before treatment and at week 52, were evaluated under blinded conditions by an independent expert with the use of the Knodell and Ishak histologic scoring systems. ${ }^{20,21}$

The study was conducted in compliance with the ethics principles of the Declaration of Helsinki and was consistent with Good Clinical Practice guidelines and applicable local regulatory requirements, including institutional-review-board approval. All patients provided written informed consent. The informed-consent forms discussed alternative treatment with interferon, lamivudine, and adefovir dipivoxil in countries where these therapies were available. Clinical data were collected and monitored by Quintiles. The sponsors, Idenix Pharmaceuticals and Novartis Pharmaceuticals, conducted predefined statistical analyses; the investigators had full access to the data and contributed substantially to study design, data collection, and data analysis. The manuscript was written in collaboration by the first and last authors; all the other authors were actively involved in review of the manuscript and approval of the final version. The academic authors vouch for the veracity and completeness of the data and data analyses.

\section{STUDY END POINTS}

The primary efficacy end point was therapeutic response, defined as a reduction in the serum HBV DNA level to fewer than $5 \log _{10}$ copies per milliliter, as recommended in available treatment guidelines, ${ }^{22,23}$ coupled with either normalization of the alanine aminotransferase level or loss of detect- able HBeAg. This composite end point captures indicators of liver disease and viral suppression used in clinical practice, similar to composite end points used in previous interferon and lamivudine trials. ${ }^{24-28}$

Histologic response, the key secondary efficacy end point, was defined as a reduction of at least two points in the Knodell necroinflammatory score, with no worsening in the Knodell fibrosis score. Other secondary efficacy measures included changes in the serum HBV DNA level, HBeAg and HBsAg loss and seroconversion, virologic response (a serum HBV DNA level below $5 \log _{10}$ copies per milliliter and HBeAg loss), ${ }^{29}$ and normalization of the serum alanine aminotransferase level. Primary treatment failure was defined as completion of at least 24 weeks of treatment without two consecutive measurements of serum HBV DNA levels below $5 \log _{10}$ copies per milliliter. Safety evaluations included discontinuation of the study drug and analyses of adverse events and graded laboratory abnormalities.

\section{HBV GENOTYPING, VIRAL BREAKTHROUGH, AND RESISTANCE}

Viral breakthrough was defined as at least two consecutive determinations of an increase in HBV DNA by at least $1 \log _{10}$ copy per milliliter from nadir during 48 weeks of therapy, a definition consistent with recent recommendations. ${ }^{30,31}$ Resistance was defined as viral breakthrough with treatment-emergent resistance mutations. ${ }^{31}$ HBV DNA was amplified by polymerase chain reaction (PCR) from serum samples at screening or at baseline from all patients, serum samples at week 48 from patients with viral breakthrough, and from patients who received telbivudine and who had more than $3 \log _{10}$ copies of residual HBV DNA per milliliter at week 52. The 344-codon reverse transcriptase domain of the HBV polymerase gene was sequenced at an independent laboratory (Delft Diagnostic Laboratory). This automated method detects potential resistance mutations that comprise at least $25 \%$ of the amplified viral DNA and is consistent with previous methods. ${ }^{32-35}$

\section{EARLY ANTIVIRAL RESPONSE VERSUS SUBSEQUENT OUTCOMES}

Prespecified analyses assessed relationships between early antiviral responses and efficacy and resistance outcomes at 1 year. Patients were categorized at week 24 according to PCR analysis as being negative for serum HBV DNA, as having de- 
tectable but fewer than $3 \log _{10}$ copies of HBV DNA per milliliter, as having from 3 to $4 \log _{10}$ copies per milliliter, or as having more than $4 \log _{10}$ copies per milliliter.

\section{STATISTICAL ANALYSIS}

The study design provided $99 \%$ power to demonstrate noninferiority of telbivudine to lamivudine for therapeutic response, assuming a noninferiority criterion of 15 percentage points, with enrollment of at least $600 \mathrm{HBeAg}$-positive and 400 HBeAg-negative patients. Analyses were based on all patients randomly assigned to treatment who received at least one dose of study medication. Analyses of histologic response included all patients with pretreatment liver-biopsy specimens that could be evaluated, as in previous studies. ${ }^{32-35}$ The primary analysis occurred at week 52, with longer-term assessments at week 104. An independent data and safety monitoring board and an external data-analysis center monitored safety. The patients, investigators, and sponsor remained unaware of treatment assignments throughout the study.

The study was intended to demonstrate effects in both HBeAg subpopulations or in the pooled population, if trends in the subpopulations warranted pooling. The primary end point was assessed by a three-step method. ${ }^{36}$ First, both HBeAg subpopulations were analyzed separately with an alpha level of 0.04 (95.68\% confidence interval). If both subpopulations met the noninferiority criteria (i.e., if confidence intervals for the treatment difference exceeded $-15 \%$ ), treatments would be compared for superiority within each subpopulation. If statistical significance was not established within both HBeAg subpopulations, a statistical test for interaction between the treatment group and HBeAg subpopulations was planned, with significance defined at the alpha level of 0.15.37 With no interaction, a statistical analysis for the overall patient population would be performed with an alpha level of 0.000933 to protect the overall alpha at 0.00125 .

Demonstration of noninferiority was a precursor to superiority testing. For the primary efficacy end point, noninferiority criteria were met in both HBeAg subpopulations, but superiority was not established for the primary end point in the HBeAg-negative population. HBeAg subpopulations were not pooled because of this statistical interaction between treatment effect and HBeAg subpopulation. For secondary end points, treatment effects were compared, first for noninferiority and then for superiority, according to a prespecified hierarchy.

Treatment comparisons of categorical end points were assessed by a weighted Cochran-MantelHaenszel method adjusted for randomization strata. For continuous variables, analysis of variance was performed with each stratified group as a factor. Reported P values are two-sided and were not adjusted for multiple testing.

\section{RESULTS}

\section{PATIENTS}

Six hundred eighty-three patients were assigned to receive telbivudine and 687 to receive lamivudine; 3 patients declined to participate further after undergoing randomization. The intention-totreat population consisted of 921 patients with HBeAg-positive chronic hepatitis B and 446 patients with HBeAg-negative chronic hepatitis B. The treatment groups were well matched at baseline for demographic and disease characteristics (Table 1). Eighteen patients receiving telbivudine (2.6\%) and 32 receiving lamivudine (4.7\%) withdrew before week 52. Among these, two in the telbivudine group $(0.3 \%)$ and eight in the lamivudine group (1.2\%) discontinued treatment because of adverse events, clinical disease progression, or lack of efficacy. Two of these patients - one with myopathy in the telbivudine group and one with urticaria in the lamivudine group - discontinued treatment because of serious adverse events that possibly were related to the study drugs.

\section{THERAPEUTIC AND HISTOLOGIC RESPONSES}

For all study end points, noninferiority criteria were met for telbivudine as compared with lamivudine, allowing for superiority testing. Among HBeAg-positive patients at week 52, significantly more patients in the telbivudine group than in the lamivudine group had either a therapeutic or a histologic response (Table 2). Among HBeAg-negative patients, the rates of therapeutic and histologic response were similar in both treatment groups at week 52 , and thus the noninferiority criteria were met.

\section{HBV DNA RESPONSES}

Among both HBeAg-positive patients and HBeAgnegative patients, reduction in serum HBV DNA 


\begin{tabular}{|c|c|c|c|c|}
\hline \multirow[t]{2}{*}{ Characteristic } & \multicolumn{2}{|c|}{ HBeAg-Positive Patients } & \multicolumn{2}{|c|}{ HBeAg-Negative Patients } \\
\hline & $\begin{array}{l}\text { Telbivudine } \\
(\mathrm{N}=458)\end{array}$ & $\begin{array}{l}\text { Lamivudine } \\
\qquad(\mathrm{N}=463)\end{array}$ & $\begin{array}{l}\text { Telbivudine } \\
(\mathrm{N}=222)\end{array}$ & $\begin{array}{l}\text { Lamivudine } \\
\qquad(\mathrm{N}=224)\end{array}$ \\
\hline Years of age - mean (range) & $32(16-63)$ & $33(16-67)$ & $43(17-68)$ & $43(18-68)$ \\
\hline Male sex — no. (\%) & $333(73)$ & $351(76)$ & $174(78)$ & 177 (79) \\
\hline Weight in kg — mean (range) & $66(38-126)$ & $68(38-150)$ & $72(42-123)$ & $71(45-148)$ \\
\hline \multicolumn{5}{|l|}{ Race or ethnic group — no. (\%)† } \\
\hline Chinese & $265(57.9)$ & $265(57.2)$ & $116(52.3)$ & $102(45.5)$ \\
\hline Non-Chinese Asian & $115(25.1)$ & $106(22.9)$ & $29(13.1)$ & $42(18.8)$ \\
\hline White & $52(11.4)$ & $55(11.9)$ & $46(20.7)$ & $56(25.0)$ \\
\hline Black & $4(0.9)$ & $7(1.5)$ & $3(1.4)$ & $3(1.3)$ \\
\hline Latino & $2(0.4)$ & $4(0.9)$ & $2(0.9)$ & $4(1.8)$ \\
\hline Middle Eastern or Indian & $8(1.7)$ & $7(1.5)$ & $6(2.7)$ & $4(1.8)$ \\
\hline Other & $12(2.6)$ & $19(4.1)$ & $20(9.0)$ & $13(5.8)$ \\
\hline \multicolumn{5}{|l|}{ HBV genotype - no. (\%) } \\
\hline A & $24(5.2)$ & $31(6.7)$ & $12(5.4)$ & $14(6.2)$ \\
\hline B & $129(28.2)$ & $113(24.4)$ & $59(26.6)$ & $59(26.3)$ \\
\hline C & $259(56.6)$ & $258(55.7)$ & $89(40.1)$ & $86(38.4)$ \\
\hline $\mathrm{D}$ & $42(9.2)$ & $54(11.7)$ & $57(25.7)$ & $64(28.6)$ \\
\hline Other or unknown & $4(0.9)$ & $7(1.5)$ & $5(2.3)$ & $1(0.4)$ \\
\hline \multicolumn{5}{|l|}{ Serum alanine aminotransferase $-I U /$ litert: } \\
\hline Mean & $146.4 \pm 5.37$ & $158.9 \pm 6.30$ & $137.0 \pm 6.94$ & $143.7 \pm 8.74$ \\
\hline Median (range) & $111.0(19-1137)$ & $111.0(25-1133)$ & $99.0(31-569)$ & $98.5(12-982)$ \\
\hline \multicolumn{5}{|l|}{ Serum HBV DNA — $\log _{10}$ copies/ml } \\
\hline Mean & $9.5 \pm 0.09$ & $9.5 \pm 0.09$ & $7.7 \pm 0.12$ & $7.4 \pm 0.10$ \\
\hline Median (range) & $9.6(3.8-16.0)$ & $9.6(3.6-16.1)$ & $7.2(3.0-13.0)$ & $7.1(3.7-12.1)$ \\
\hline \multicolumn{5}{|l|}{ Liver histologic findings $\int$} \\
\hline $\begin{array}{l}\text { Mean total Knodell Histologic Activity } \\
\text { Index score }\end{array}$ & 8.9 & 9.0 & 9.0 & 9.6 \\
\hline Mean Knodell necroinflammatory score & 7.4 & 7.3 & 7.3 & 7.6 \\
\hline Mean Ishak fibrosis score & 2.1 & 2.2 & 2.3 & 2.5 \\
\hline
\end{tabular}

* $\mathrm{HBeAg}$ denotes hepatitis B e antigen, and HBV hepatitis B virus. Plus-minus values are means $\pm \mathrm{SE}$.

$\dagger$ Race or ethnic group was self-assessed.

$\checkmark$ The upper limit of normal for serum alanine aminotransferase was $48 \mathrm{IU}$ per liter for men and $37 \mathrm{IU}$ per liter for women.

$\int$ The analysis included the $872 \mathrm{HBeAg}$-positive patients ( $94.7 \%$ of the total intention-to-treat population) with baseline liver-biopsy findings that could be evaluated. The Knodell Histologic Activity Index score can range from 0 to 22 , with higher scores indicating more severe disease. The Knodell inflammatory score can range from 0 to 18 , with higher scores indicating more severe chronic hepatitis. The Ishak fibrosis score is based on a scale of 0 to 6 , where 0 indicates no fibrosis and 5 or higher indicates cirrhosis.

levels at week 52 was significantly greater in the telbivudine group than in the lamivudine group (Table 2). The difference was evident by week 12 in HBeAg-positive patients (reductions of $5.71 \log _{10}$ copies per milliliter for telbivudine and $5.42 \log _{10}$ copies per milliliter for lamivudine, $\mathrm{P}=0.01$ ) and by week 8 in HBeAg-negative patients (reductions of $4.36 \log _{10}$ copies per milliliter for telbivudine and $4.08 \log _{10}$ copies per milliliter for lamivudine, $\mathrm{P}=0.02$ ), and it persisted through week 52 (Fig. $1 \mathrm{~A}$ and $1 \mathrm{~B})$.

At week 52, the proportion of patients in whom 


\begin{tabular}{|c|c|c|c|c|c|c|c|c|c|c|c|c|c|c|}
\hline 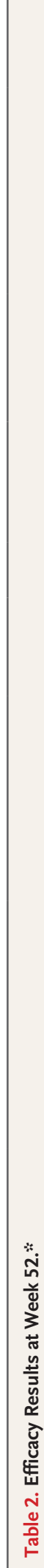 & 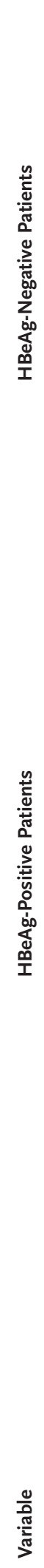 & 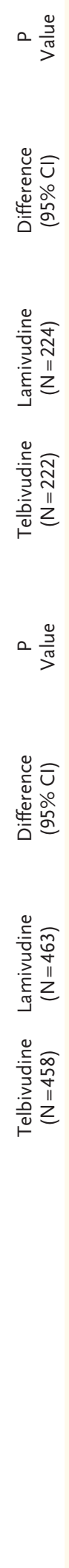 & 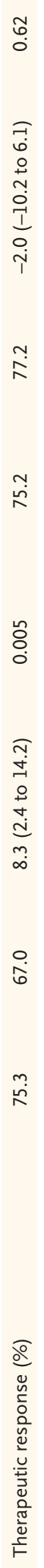 & 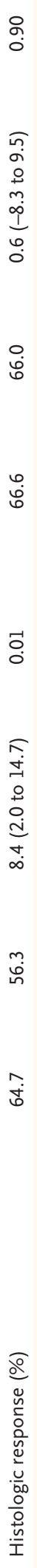 & 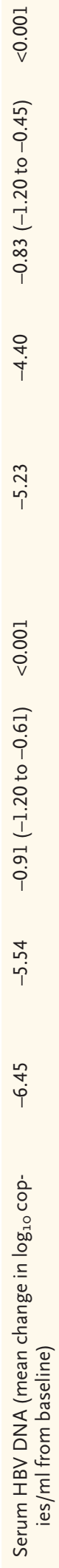 & 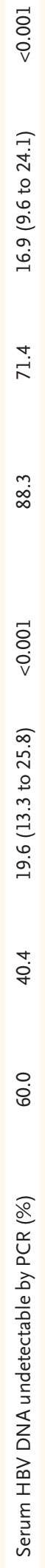 & 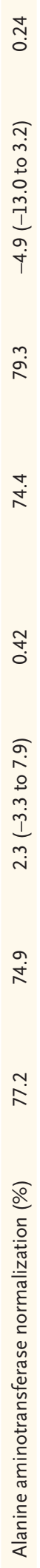 & 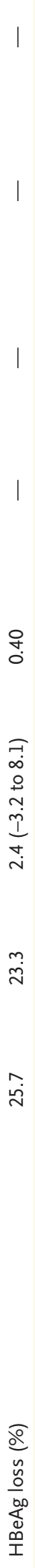 & 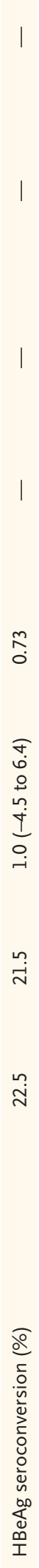 & 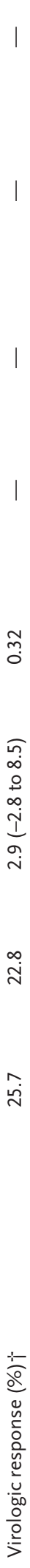 & 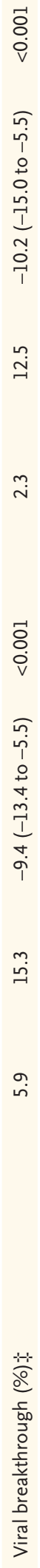 & 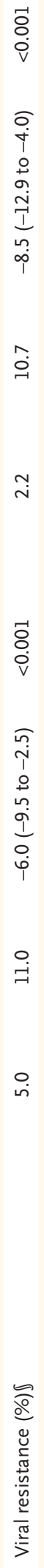 & $\begin{array}{l}\vec{T} \\
0 \\
0 \\
\dot{0} \\
0 \\
\dot{+} \\
\stackrel{m}{m} \\
\stackrel{i}{i}\end{array}$ & 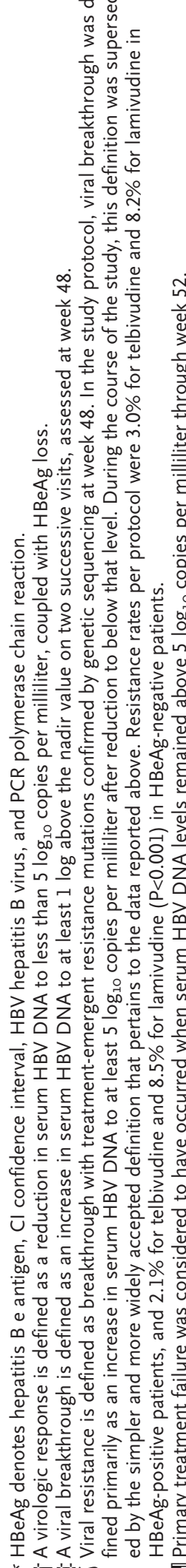 \\
\hline
\end{tabular}




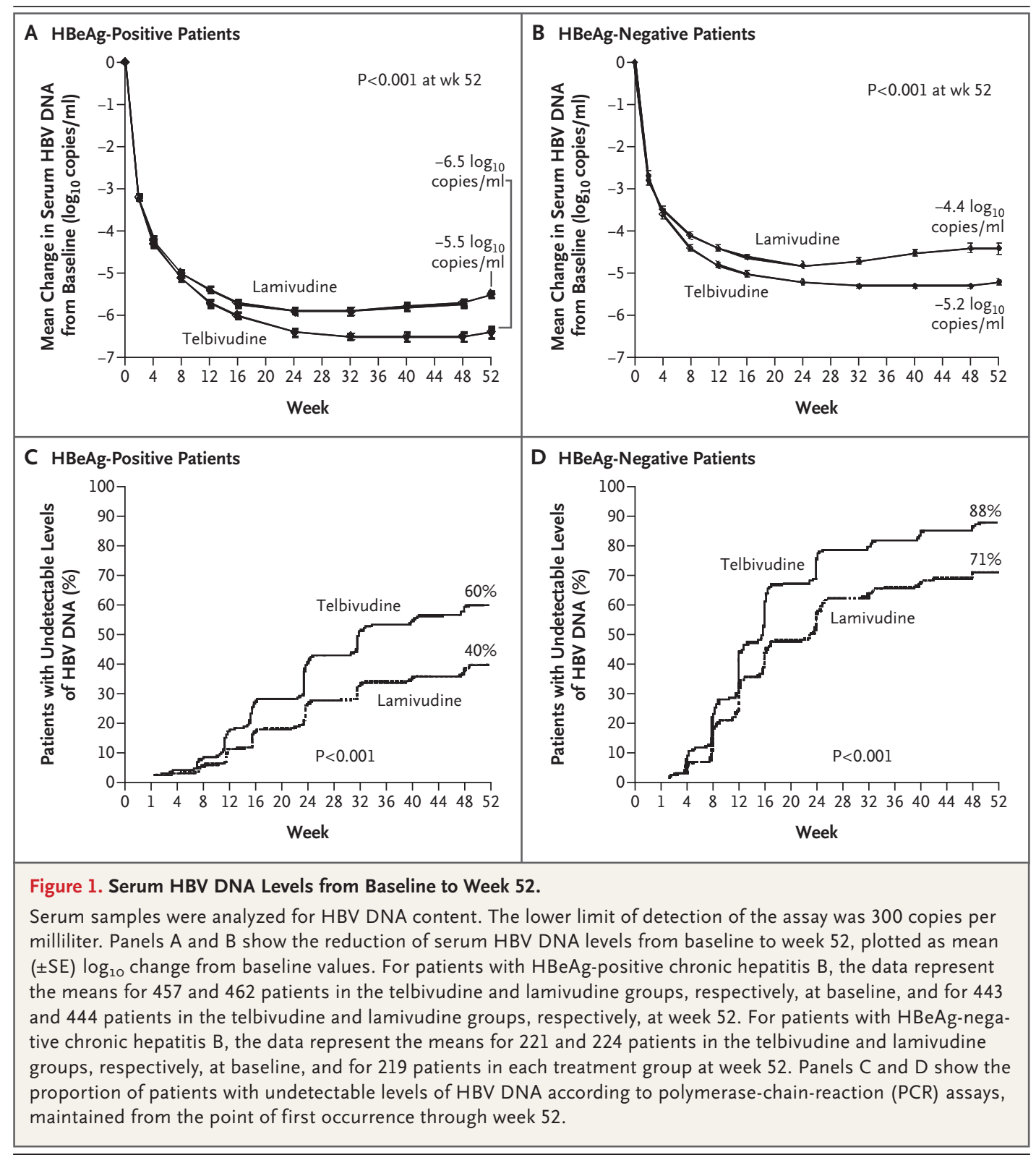

serum HBV DNA levels were undetectable by PCR assay was significantly greater in the telbivudine group than in the lamivudine group among HBeAg-positive patients ( $60.0 \%$ vs. $40.4 \%, \mathrm{P}<0.001)$ and HBeAg-negative patients $(88.3 \%$ vs. $71.4 \%$, $\mathrm{P}<0.001$ ) (Table 2). The mean time required for serum HBV DNA to become undetectable by PCR assay was significantly shorter in the telbivudine group than in the lamivudine group among HBeAg-positive patients (34 weeks vs. 39 weeks, $\mathrm{P}<0.001)$ and $\mathrm{HBeAg}$-negative patients (20 weeks vs. 26 weeks, $\mathrm{P}<0.001$ ) (Fig. 1C and 1D). Primary treatment failure was less frequent with telbivu- dine than with lamivudine among both HBeAgpositive and HBeAg-negative patients, but the difference was significant only for HBeAg-positive patients (Table 2).

\section{HBEAg AND HBSAg RESPONSES}

Among HBeAg-positive patients, $25.7 \%$ of those in the telbivudine group and $23.3 \%$ of those in the lamivudine group had HBeAg loss $(\mathrm{P}=0.40)$ and $22.5 \%$ of those in the telbivudine group and $21.5 \%$ of those in the lamivudine group had HBeAg seroconversion ( $\mathrm{P}=0.73$ ) (Table 2). Among the 69\% of patients with pretreatment alanine aminotrans- 
ferase levels at least twice the upper limit of normal - a group generally considered the best candidates for treatment ${ }^{22,23}$ - HBeAg loss occurred in $30.8 \%$ and $26.2 \%$ of patients receiving telbivudine and lamivudine, respectively $(\mathrm{P}=0.22)$, and HBeAg seroconversion occurred in $26.6 \%$ and $24.1 \%$, respectively $(\mathrm{P}=0.49)$. Less than $1 \%$ of patients in each treatment group had HBsAg seroconversion.

\section{BIOCHEMICAL RESPONSE}

The rates of normalization of serum alanine aminotransferase at week 52 were high (levels more than $70 \%$ ) in both treatment groups, with results meeting noninferiority criteria in the HBeAgpositive and in the HBeAg-negative subgroups (Table 2).

\section{ADDITIONAL HISTOLOGIC ANALYSES}

Among HBeAg-positive patients, the mean Knodell Histologic Activity Index scores (range, 0 to 22, with higher scores indicating more severe disease) improved by 3.92 and 3.64 points in patients receiving telbivudine and in those receiving lamivudine, respectively (difference, 0.28 ; $95 \%$ confidence interval $[\mathrm{CI}],-0.23$ to 0.79 ); among HBeAg-negative patients, the scores improved by 3.85 and 3.73 points, respectively (difference, 0.12 ; $95 \% \mathrm{CI},-0.59$ to 0.82 ). Among HBeAg-positive patients with marked pretreatment bridging fibrosis or cirrhosis and who had Ishak fibrosis scores of 4 to 6 (where 0 indicates no fibrosis and 6 indicates cirrhosis), the Ishak fibrosis scores improved to between 0 and 3 in $68 \%$ of patients receiving telbivudine and $61 \%$ of patients receiving lamivudine (difference, $7 \%$; $95 \% \mathrm{CI},-16$ to $29 \%$ ); the corresponding figures for HBeAg-negative patients were $59 \%$ and $46 \%$ (difference, $13 \%$; $95 \% \mathrm{CI},-14$ to $40 \%$ ). In contrast, among patients with baseline Ishak fibrosis scores of 0 to 3, progression to a score greater than 3 by week 52 occurred in only $1 \%$ of patients in either $\mathrm{HBeAg}$ subgroup who were taking either telbivudine or lamivudine.

\section{BREAKTHROUGH AND RESISTANCE}

Viral breakthrough and genotypic resistance were significantly less common in patients receiving telbivudine than in those receiving lamivudine (Table 2). Resistance developed in $5.0 \%$ and $2.3 \%$ of HBeAg-positive and HBeAg-negative patients who received telbivudine, respectively, as compared with
$11.0 \%$ and $10.7 \%$ of HBeAg-positive and HBeAgnegative patients who received lamivudine, respectively ( $\mathrm{P}<0.001$ for both comparisons).

Consistent with previous reports, M204I was the only signature mutation associated with telbivudine resistance; secondary mutations L80I/V and L80I/V+L180M accompanied M204I in 2.2\% and $0.3 \%$, respectively, of the patients who received telbivudine. ${ }^{14,38,39}$ Overall, the M204I mutation was detected in 46 of the 115 patients who received telbivudine and who had serum HBV DNA levels of at least 1000 copies per milliliter at week 52 (including patients with viral breakthrough), representing $6.8 \%$ of all telbivudine recipients in the study. Variants harboring mutations at the A181 and L229 codons were detected sporadically, with 16 and 6 occurrences, respectively, among the 115 telbivudine recipients with detectable HBV DNA, but these were not associated with viral breakthrough without concomitant detection of M204I. Lamivudine resistance was based on the signature mutations M204I and M204V; M204V was accompanied by the L180M secondary mutation, whereas M204I was seen alone or with the secondary mutation L80I/V. ${ }^{31,39}$

\section{EARLY VIRAL SUPPRESSION AND 1-YEAR EFFICACY OUTCOMES}

The distribution of patients according to HBV DNA levels at week 24 (Fig. 2) is consistent with the greater viral suppression observed with telbivudine (Fig. 1). At week 24, more patients in the telbivudine group than in the lamivudine group were negative for HBV DNA according to PCR, whereas residual HBV DNA levels greater than $4 \log _{10}$ copies per milliliter were more frequent in patients in the lamivudine group than in those in the telbivudine group.

In the combined treatment groups, low HBV DNA levels at week 24 were associated with favorable 1-year efficacy outcomes (Fig. 3A). Of HBeAg-positive patients at week 24, $41 \%$ with undetectable levels of HBV DNA on PCR underwent seroconversion by week 52 as compared with $4 \%$ of patients with more than $4 \log _{10}$ copies of HBV DNA per milliliter. Similar correlations were observed between HBV DNA levels at week 24 and the proportion of patients with alanine transaminase normalization at week 52 .

At week 24, in HBeAg-positive patients in both treatment groups combined, resistance occurred in only $2 \%$ of patients who were negative for HBV 


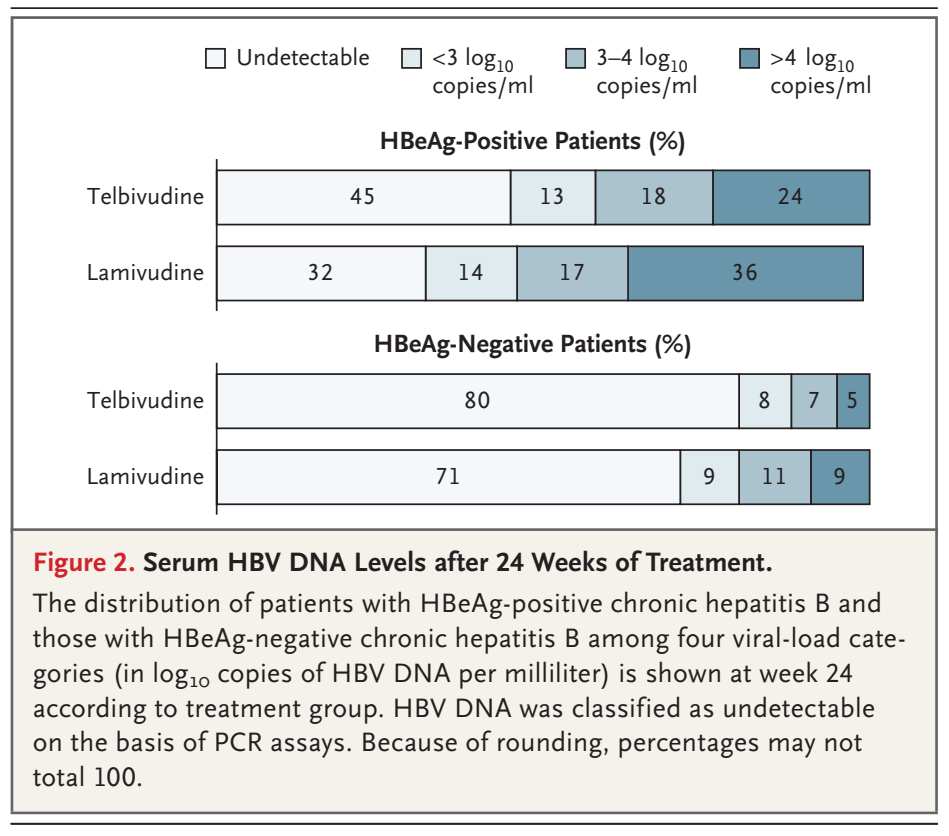

DNA on PCR, as compared with $15 \%$ of patients with viral loads above $4 \log _{10}$ copies per milliliter (Fig. 3A). A similar pattern was evident for $\mathrm{HBeAg}$ negative patients. The pattern of relationships between HBV DNA levels at week 24 and subsequent resistance was similar for telbivudine and lamivudine. However, viral suppression was significantly greater and resistance was less frequent in the telbivudine group than in the lamivudine group within each viral-load category at week 24 (Fig. 3B). Multivariate regression analyses identified viral load at week 24 as the most significant predictor of 1-year efficacy outcomes and resistance.

\section{SAFETY AND ADVERSE EVENTS}

The frequencies of adverse events through week 52 were similar for patients who received telbivudine and for those who received lamivudine (Table 3). Serious adverse events (defined according to criteria adapted from the Division of AIDS, National Institute of Allergy and Infectious Diseases ${ }^{40}$ ), regardless of attributability to study drug, were reported for 18 patients in the telbivudine group (2.6\%) and 33 in the lamivudine group (4.8\%).

Elevations in creatine kinase levels through week 52 were more common in recipients of telbivudine than in recipients of lamivudine (Table 3). Creatine kinase levels were elevated in $15 \%$ of study patients before treatment, a finding consistent with the frequent elevations in creatine kinase levels reported in patients who received placebo in previous studies. ${ }^{32,34,41}$ Grade 3 or 4 elevations in creatine kinase levels (at least seven times the upper limit of normal), which were observed in $7.5 \%$ of patients in the telbivudine group and $3.1 \%$ of those in the lamivudine group, decreased spontaneously during drug treatment to grade 2 or lower by the next visit in $66.7 \%$ of the patients in the telbivudine group and $73.9 \%$ of those in the lamivudine group. Patterns of clinical adverse events, including infrequent muscle-related symptoms, correlated poorly with elevations in creatine kinase levels and were similar in the two study groups. Myopathy, characterized by muscle pain and weakness and moderately elevated creatine kinase levels before and during treatment, was reported in one patient 11 months after initiation of telbivudine. When telbivudine was discontinued, creatine kinase levels returned to normal within 1 month and symptoms resolved over a period of 9 to 12 months.

Grade 3 or 4 elevations in alanine aminotransferase and aspartate aminotransferase levels during treatment were less frequent in the telbivudine group than in the lamivudine group (Table 3 ). Grade 3 or 4 elevations in alanine aminotransferase levels were noted in $13.1 \%$ of patients receiving lamivudine and $12.5 \%$ of patients receiving telbivudine who had viral breakthrough. One patient with lamivudine resistance had liver failure and received a liver transplant. After week 24, alanine aminotransferase flares of at least $500 \mathrm{IU}$ per liter and at least twice the baseline value were more common with lamivudine $(2.2 \%)$ than telbivudine $(0.4 \%)$.

\section{DISCUSSION}

In patients with $\mathrm{HBeAg}$-positive chronic hepatitis $B$, telbivudine was superior to lamivudine for the primary and key secondary efficacy end points of therapeutic response and histologic response; in HBeAg-negative patients, telbivudine and lamivudine achieved similar rates of therapeutic and histologic response. In both HBeAg-positive and HBeAg-negative patients, telbivudine had greater antiviral efficacy than did lamivudine. The mechanism underlying the effect of pretreatment $\mathrm{HBeAg}$ status on therapeutic and histologic response is uncertain, but it may derive from the lower baseline HBV DNA levels and high viral clearance rates observed in HBeAg-negative patients. Results may differ with longer-term follow-up, as treatment-related differences in antiviral potency 


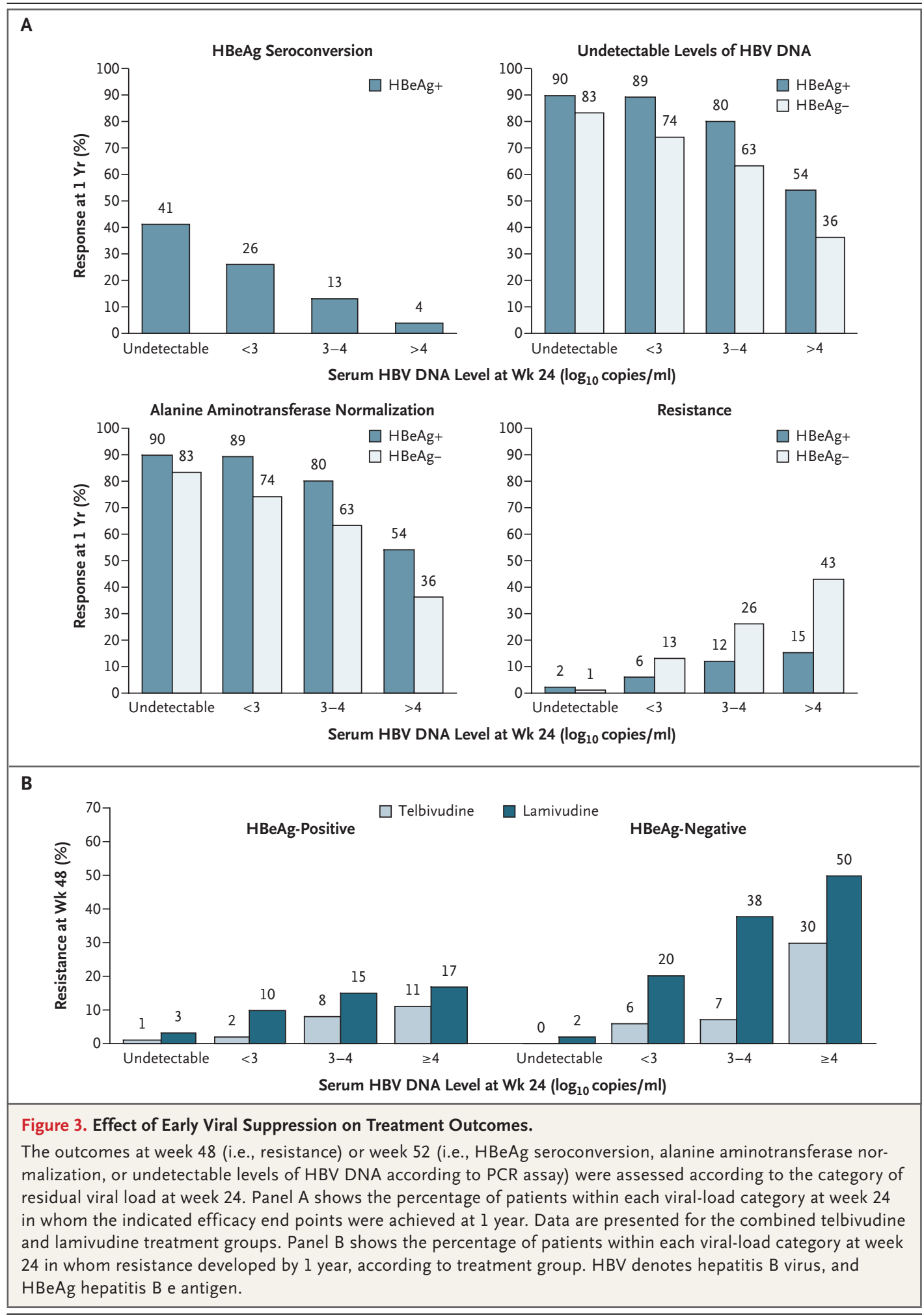

and resistance assume greater importance for determining therapeutic outcomes.

The lower resistance rates observed with telbivudine than with lamivudine are probably due in part to the greater antiviral efficacy of telbivudine. Consistent with in vitro findings, data concerning clinical resistance confirm the M204I mutation as the primary basis for telbivudine re- 


\begin{tabular}{|c|c|c|}
\hline Event & $\begin{array}{l}\text { Telbivudine } \\
(\mathrm{N}=680)\end{array}$ & $\begin{array}{l}\text { Lamivudine } \\
(\mathrm{N}=687)\end{array}$ \\
\hline \multicolumn{3}{|l|}{ Clinical adverse events — \%* } \\
\hline Any adverse event & 73 & 69 \\
\hline Upper respiratory tract infection & 12 & 12 \\
\hline Headache & 10 & 12 \\
\hline Nasopharyngitis & 10 & 10 \\
\hline Fatigue & 10 & 9 \\
\hline Increased blood creatine kinase & 8 & 6 \\
\hline Postprocedure pain & 6 & 5 \\
\hline Cough & 6 & 6 \\
\hline Upper abdominal pain & 5 & 7 \\
\hline Influenza & 5 & 5 \\
\hline Diarrhea & 5 & 4 \\
\hline Nausea & 5 & 4 \\
\hline Dizziness & 4 & 5 \\
\hline Dyspepsia & 2 & 5 \\
\hline \multicolumn{3}{|l|}{$\begin{array}{c}\text { Grade } 3 \text { or } 4 \text { laboratory abnormalities } \\
\text { — no. (\%) } \dagger\end{array}$} \\
\hline Alanine aminotransferase & $25(3.7)$ & $43(6.3)$ \\
\hline Aspartate aminotransferase & $18(2.6)$ & $32(4.7)$ \\
\hline Creatine kinase & $51(7.5)$ & $21(3.1)$ \\
\hline Lipase & $12(1.8)$ & $22(3.2)$ \\
\hline Amylase & $1(0.1)$ & $2(0.3)$ \\
\hline Absolute neutrophil count & $13(1.9)$ & $9(1.3)$ \\
\hline Platelet count & $5(0.7)$ & $4(0.6)$ \\
\hline Total bilirubin & 0 & $2(0.3)$ \\
\hline
\end{tabular}

* All clinical adverse events occurring in at least $5 \%$ of patients in either treatment group are listed, regardless of their attributability to the study drug.

$\uparrow$ The severity of laboratory abnormalities was graded according to criteria adapted from the Division of AIDS, National Institute of Allergy and Infectious Diseases. ${ }^{40}$ Grade 3 elevations in aminotransferase levels are those 3 to 10 times baseline; grade 4 elevations in aminotransferase levels are those at least 10 times baseline or accompanied by evidence of hepatic failure. Grades 3 and 4 elevations in creatine kinase levels are those at least 7 times the upper limit of normal.

sistance, in contrast to lamivudine resistance, which is associated with either the M204I or the M204V mutation. ${ }^{38} \mathrm{HBV}$ with either of these mutations is less susceptible to inhibition by nucleoside analogues but remains sensitive in vitro to the nucleotide analogues adefovir and tenofovir. ${ }^{31}$

This study confirms previously described associations between greater reductions in HBV DNA levels at week 24 and better subsequent therapeutic outcomes, including lower resistance. ${ }^{14,18,19}$ These relationships were similar for both study drugs and may also apply to other agents for hepatitis B. The greater viral suppression achieved with more potent drugs predicts improved clinical outcomes overall. ${ }^{8,10}$ Future studies of patients with suboptimal responses may determine whether early treatment modification, using drugs with complementary resistance profiles, can improve subsequent outcomes.

The adverse event data in this trial were consistent with previous findings and preclinical toxicologic data ${ }^{12,14,42}$ and suggest that telbivudine and lamivudine have similar safety profiles. Ontreatment aminotransferase flares after the first 6 months of treatment were less frequent with telbivudine, in accord with the lower incidence of viral breakthrough. Elevations in creatine kinase levels were more frequent with telbivudine but were not predictive of muscle-related adverse events. The occurrence of myopathy in a patient treated with telbivudine suggests that any persistent, unexplained muscle-related symptoms should be evaluated promptly.

As for all agents, the clinical role of telbivudine will be determined by efficacy, safety, and resistance considerations. Lamivudine was chosen as the comparator in this trial because it was the treatment of choice when the trial was initiated. Telbivudine has not been compared directly with other recently approved agents, such as entecavir. However, in separate trials, both telbivudine and entecavir have shown greater antiviral effects than have adefovir and lamivu-

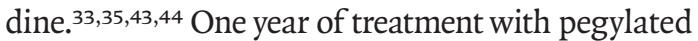
interferon has also been shown to be superior to 1 year of lamivudine when efficacy is assessed 24 weeks after both agents have been stopped. ${ }^{24,25}$ However, we are unaware of any trials that have compared the efficacy of 1 year of pegylated interferon with that of longer-term treatment with nucleoside or nucleotide analogues.

Maintaining safety and antiviral efficacy is critical with extended therapy. Loss of response due to cumulative resistance, treatment failure, or both has been observed with all nucleoside or nucleotide therapies for hepatitis B. Within 4 years after initiation of treatment, the cumulative incidence of lamivudine resistance approaches $70 \%{ }^{39}$ Adefovir resistance was observed in $29 \%$ of $\mathrm{HBeAg}$ negative patients after 5 years of treatment and in 16 of 38 HBeAg-positive patients with virologic failure after 110 to 279 weeks. ${ }^{45}$ With entecavir, cumulative resistance was $0.8 \%$ at 4 years 
according to an analysis of 120 of the 663 patients not previously treated with nucleosides from phase 3 trials. $^{46}$ Similarly, cumulative telbivudine resistance is likely to increase as therapy is extended. Long-term studies are needed to understand the cumulative prevalence and clinical effect of resistance to these agents.

The multiple therapeutic choices now available for hepatitis B will enhance the ability of clinicians to maintain long-term control of HBV replication, ultimately improving clinical outcomes for more patients. These results support telbivudine as an effective therapy for patients with chronic hepatitis $\mathrm{B}$.

Supported by Idenix Pharmaceuticals and Novartis Pharmaceuticals.

Dr. Lai reports receiving consulting fees from Bristol-Myers Squibb, Idenix Pharmaceuticals, and GlaxoSmithKline, lecture fees from Bristol-Myers Squibb, Idenix Pharmaceuticals, and GlaxoSmithKline, and grant support from Bristol-Myers Squibb, Idenix Pharmaceuticals, and Novartis Pharmaceuticals; Dr. Gane, consulting fees from Idenix Pharmaceuticals, Novartis Pharmaceuticals, and GlaxoSmithKline and lecture fees from Novartis Pharmaceuticals and GlaxoSmithKline; Dr. Liaw, consulting fees from Bristol-Myers Squibb, Roche, Schering-Plough, and Novartis, lecture fees from Bristol-Myers Squibb and Novartis, and grant support from Roche, Bristol-Myers Squibb, Novartis, and SciClone Pharmaceuticals; Dr. Heathcote, consulting fees from Idenix Pharmaceuticals and Novartis Pharmaceuticals and grant support from Idenix Pharmaceuticals, Gilead Sciences, Debio,
Schering-Plough Pharmaceuticals, Vertex Pharmaceuticals, Human Genome Sciences, Roche, Pharmasett, and Novartis; and Dr. Bzowej, consulting fees from Idenix Pharmaceuticals and Gilead Sciences, lecture fees from Idenix Pharmaceuticals and Novartis Pharmaceuticals, and grant support from Idenix Pharmaceuticals, Gilead Sciences, Roche, Novartis Pharmaceuticals, Vertex Pharmaceuticals, GlaxoSmithKline, and Schering-Plough. Dr. Naoumov reports being an employee of Novartis Pharmaceuticals and receiving consulting fees from Gilead Sciences, Roche, Idenix Pharmaceuticals, and Novartis Pharmaceuticals, lecture fees from GlaxoSmithKline, Schering-Plough, Idenix Pharmaceuticals, and Novartis Pharmaceuticals, and grant support from Idenix Pharmaceuticals and Gilead Sciences. Dr. Di Bisceglie reports receiving consulting fees from Idenix Pharmaceuticals, Roche, Novartis Pharmaceuticals, Vertex Pharmaceuticals, Bristol-Myers Squibb, Pharmasset, Metabasis Therapeutics, SciClone Pharmaceuticals, and Chiron Corporation and grant support from Roche Pharmaceuticals, Gilead Sciences, and Vertex Pharmaceuticals; Dr. Zeuzem, consulting fees from Gilead Sciences, Roche, Idenix Pharmaceuticals, and Novartis Pharmaceuticals and lecture fees from Bristol-Myers Squibb, Gilead Sciences, Roche, Idenix Pharmaceuticals, and Novartis Pharmaceuticals; and Dr. Goodman, consulting fees from Schering-Plough and Gilead Sciences and grant support from Idenix Pharmaceuticals, Bristol-Myers Squibb, SciClone Pharmaceuticals, New England Research Institutes, and GlaxoSmithKline. Dr. Chao reports having been an employee of Idenix Pharmaceuticals until June 2006 and holding equity in Idenix Pharmaceuticals and Bristol-Myers Squibb. Dr. Brown reports being a former employee of Idenix Pharmaceuticals and holding equity in Idenix Pharmaceuticals. Ms. Fielman Constance reports being a full-time employee of Idenix Pharmaceuticals and holding equity in Idenix Pharmaceuticals. No other potential conflict of interest relevant to this article was reported.

We thank Richard Boehme, Ph.D., for assistance with manuscript preparation.

APPENDIX

In addition to the authors, the Globe Study Group included the following investigators: North America - N. Afdhal, M. Bennett, S. Chan, M. Fried, J. Galati, N. Gitlin, E. Godofsky, S.H. Han, T. Hassanein, N. Hilzenrat, M. Khalili, P. Kwan, S. Lee, A. Lok, P. Lynch, A. Min, G. Minuk, M. Mutchnick, T. Nguyen, C. O’Brien, R. Pollard, R. Reindollar, M. Shiffman, M. Tong, N. Tsai, F. Wong; Europe - M. Beaugrand, A. Boron-Kaczmarska, M. Bourliere, M. Buti, Y. Cakaloglu, G. Calleri, J. Crespo Garcia, M. Diago, G. Dusheiko, A. Gladysz, J.D. Grange, S. Gurel, P. Husa, S. Karayalcin, O. Ovunc Kurdas, T. Mach, M. Manns, D. Mutimer, G. Papatheodoridis, A. Perperas, T. Poynard, M. Rizzetto, M. Rodriguez Garcia, D. Samuel, J. Sperl, A. Tran, C. Trepo, P. Urbanek, M. Volfova, J.P. Zarski; Asia - K. Akarawong, T.T. Chang, Y.C. Chao, M. Cho, H. Choi, G. Choudhuri, A. Chutaputti, J.Y. Han, Y. He, J.L. Hou, C.W. Hsu, S.G. Hwang, J.D. Jia, P. Kar, B.S. Kim, D.J. Kim, P. Komolmit, S.T. Lai, C.M. Lee, N.W.Y. Leung, S.G. Lim, W.L. Lu, P. Luengrojanakul, J. Niu, B. Prabhakar, R.R. Rai, S.K. Sarin, E.K. Teo, M. Wan, S.M. Wu, D.Z. Xu, J.Z. Xu, W.L. Yang, Y.K. Yin, X.Q. Zhou, L. Zhu; Australia and New Zealand - P. Angus, D. Crawford, G. Farrell, J. George, C. Moyes, S. Roberts, W. Sievert, S. Strasser, F. Weilert.

REFERENCES

1. McMahon BJ. Epidemiology and natural history of hepatitis B. Semin Liver Dis 2005;25:Suppl 1:3-8.

2. Fattovich G, Brollo L, Giustina G, et al. Natural history and prognostic factors for chronic hepatitis type B. Gut 1991; 32:294-8.

3. Ohata K, Hamasaki K, Toriyama K, Ishikawa H, Nakao K, Eguchi K. High viral load is a risk factor for hepatocellular carcinoma in patients with chronic hepatitis B virus infection. J Gastroenterol Hepatol 2004;19:670-5.

4. Chen CJ, Yang HI, Su J, et al. Risk of hepatocellular carcinoma across a biological gradient of serum hepatitis B virus DNA level. JAMA 2006;295:65-73.
5. Chen G, Lin W, Shen F, Iloeje UH, London WT, Evans AA. Past HBV viral load as predictor of mortality and morbidity from HCC and chronic liver disease in a prospective study. Am J Gastroenterol 2006;101:1797-803.

6. Yuan HJ, Yuen MF, Ka-Ho WD, Sablon E, Lai CL. The relationship between HBVDNA levels and cirrhosis-related complications in Chinese with chronic hepatitis B. J Viral Hepat 2005;12:373-9.

7. Yuen MF, Yuan HJ, Wong DK, et al. Prognostic determinants for chronic hepatitis B in Asians: therapeutic implications. Gut 2005;54:1610-4.

8. Mommeja-Marin $\mathrm{H}$, Mondou E, Blum MR, Rousseau F. Serum HBV DNA as a marker of efficacy during therapy for chronic HBV infection: analysis and review of the literature. Hepatology 2003;37: 1309-19.

9. Liaw YF, Sung JJ, Chow WC, et al. Lamivudine for patients with chronic hepatitis $\mathrm{B}$ and advanced liver disease. $\mathrm{N}$ Engl J Med 2004;351:1521-31.

10. Lok AS, McMahon BJ. Chronic hepatitis B. Hepatology 2007;45:507-39. [Erratum, Hepatology 2007;45:1347.]

11. Standring DN, Bridges EG, Placidi L, et al. Antiviral beta-L-nucleosides specific for hepatitis B virus infection. Antivir Chem Chemother 2001;12:Suppl 1:119-29.

12. Bridges EG. Telbivudine preclinical safety studies suggest minimal risk of 
chronic toxicity, reproductive toxicity or carcinogenicity. J Hepatol 2006;44:Suppl 2:S147.

13. Lai CL, Lim SG, Brown NA, et al. A dose-finding study of once-daily oral telbivudine in HBeAg-positive patients with chronic hepatitis B virus infection. Hepatology 2004;40:719-26.

14. Lai CL, Leung N, Teo EK, et al. A 1-year trial of telbivudine, lamivudine, and the combination in patients with hepatitis B e antigen-positive chronic hepatitis B. Gastroenterology 2005;129:528-36.

15. Hadziyannis SJ, Papatheodoridis GV. Hepatitis B e antigen-negative chronic hepatitis B: natural history and treatment. Semin Liver Dis 2006;26:130-41.

16. Di Marco V, Marzano A, Lampertico $\mathrm{P}$, et al. Clinical outcome of HBeAg-negative chronic hepatitis B in relation to virological response to lamivudine. Hepatology 2004;40:883-91.

17. Lok AS, McMahon BJ. Chronic hepatitis B: update of recommendations. Hepatology 2004;39:857-61.

18. Gauthier J, Bourne EJ, Lutz MW, et al. Quantitation of hepatitis B viremia and emergence of YMDD variants in patients with chronic hepatitis B treated with lamivudine. J Infect Dis 1999;180:1757-62. 19. Yuen MF, Sablon E, Hui CK, Yuan HJ, Decraemer H, Lai CL. Factors associated with hepatitis B virus DNA breakthrough in patients receiving prolonged lamivudine therapy. Hepatology 2001;34:785-91. 20. Knodell RG, Ishak KG, Black WC, et al. Formulation and application of a numerical scoring system for assessing histological activity in asymptomatic chronic active hepatitis. Hepatology 1981;1:431-5. 21. Ishak K, Baptista A, Bianchi L, et al. Histological grading and staging of chronic hepatitis. J Hepatol 1995;22:696-9.

22. Lok AS, McMahon BJ. Chronic hepatitis B. Hepatology 2001;34:1225-41.

23. Liaw YF, Leung $N$, Guan $R$, et al. Asian-Pacific consensus statement on the management of chronic hepatitis B: a 2005 update. Liver Int 2005;25:472-89.

24. Marcellin P, Lau GKK, Bonino F, et al. Peginterferon alfa-2a alone, lamivudine alone, and the two in combination in patients with HBeAg-negative chronic hepatitis B. N Engl J Med 2004;351:1206-17.
25. Lau GK, Piratvisuth T, Luo KX, et al. Peginterferon alfa-2a, lamivudine, and the combination for HBeAg-positive chronic hepatitis B. N Engl J Med 2005;352:2682 95.

26. Perrillo RP, Schiff ER, Davis GL, et al A randomized, controlled trial of interferon alfa-2b alone and after prednisone withdrawal for the treatment of chronic hepatitis B. N Engl J Med 1990;323:295-301.

27. Tassopoulos NC, Volpes R, Pastore G et al. Efficacy of lamivudine in patients with hepatitis B e antigen-negative/hepatitis B virus DNA-positive (precore mutant) chronic hepatitis B. Hepatology 1999;29: 889-96.

28. Lampertico P, Del Ninno E, Viganò M, et al. Long-term suppression of hepatitis $B$ e antigen-negative chronic hepatitis $B$ by 24 -month interferon therapy. Hepatology 2003;37:756-63.

29. Lok AS, Heathcote EJ, Hoofnagle JH Management of hepatitis B: 2000 - summary of a workshop. Gastroenterology 2001;120:1828-53.

30. Guideline on the clinical evaluation of medicinal products intended for treatment of hepatitis B. London: Committee for Medicinal Products for Human Use (CHMP), 2006. (Accessed November 21 2007, at http://www.emea.europa.eu/pdfs/ human/ewp/617203en.pdf. )

31. Locarnini S, Hatzakis A, Heathcote J, et al. Management of antiviral resistance in patients with chronic hepatitis B. Antivir Ther 2004;9:679-93.

32. Marcellin P, Chang TT, Lim SG, et al. Adefovir dipivoxil for the treatment of hepatitis $\mathrm{B}$ e antigen-positive chronic hepatitis B. N Engl J Med 2003;348: 808-16.

33. Chang TT, Gish RG, de Man R, et al. A comparison of entecavir and lamivudine for HBeAg-positive chronic hepatitis B. N Engl J Med 2006;354:1001-10.

34. Hadziyannis SJ, Tassopoulos NC, Heathcote EJ, et al. Adefovir dipivoxil for the treatment of hepatitis B e antigennegative chronic hepatitis B. N Engl J Med 2003:348:800-7. [Erratum, N Engl J Med 2003;348:1192.]

35. Lai CL, Shouval D, Lok AS, et al. Entecavir versus lamivudine for patients with HBeAg-negative chronic hepatitis B. N Engl
J Med 2006;354:1011-20. [Erratum, N Engl J Med 2006;354:1863.]

36. Lu HL, Huque M. Understanding on the pooled test for controlled clinical trials. Biometrical J 2000;43:909-23.

37. DerSimonian R, Laird N. Meta-analysis in clinical trials. Control Clin Trials 1986;7:177-88.

38. Standring DN, Seifer M, Patty A, et al. HBV resistance determination from the telbivudine GLOBE registration trial. J Hepatol 2006;44:Suppl 2:S191. abstract. 39. Lai CL, Dienstag J, Schiff E, et al. Prevalence and clinical correlates of YMDD variants during lamivudine therapy for patients with chronic hepatitis B. Clin Infect Dis 2003;36:687-96.

40. Division of AIDS table for grading severity of adult adverse experiences. Bethesda, MD: National Institute of Allergy and Infectious Diseases, 1992. (Accessed November 21, 2007, at http://rcc.tech-res.com/ DAIDS\%20RCC\%20Forms/ToxicityTables_ Adult_TRP_v01a.pdf.)

41. Telbivudine (Tyzeka) for chronic hepatitis B. Med Lett Drugs Ther 2007;49:11-2. 42. Lok AS, Lai CL, Leung N, et al. Longterm safety of lamivudine treatment in patients with chronic hepatitis B. Gastroenterology 2003;125:1714-22.

43. Chan HLY, Heathcote EJ, Marcellin P, et al. Treatment of hepatitis B e antigenpositive chronic hepatitis with telbivudine or adefovir: a randomized trial. Ann Intern Med (in press).

44. Leung N, Peng CY, Sollano J, et al. Entecavir (ETV) results in higher HBV-DNA reduction vs adefovir (ADV) in chronically infected $\mathrm{HBeAg}(+)$ antiviral-naive adults: 48 wk results (EARLY study). J Hepatol 2007;46:Suppl 1:S23. abstract.

45. Hepsera (adefovir dipivoxil) prescribing information. Foster City, CA: Gilead Sciences, 2006. (Accessed November 21, 2007, at http://www.gilead.com/pdf/hepsera_pi.pdf.) 46. Colonno RJ, Rose RE, Pokornowski K, Baldick CJ, Klesczewski K, Tenney DJ. Assessment at three years shows high barrier to resistance is maintained in entecavirtreated nucleoside naïve patients while resistance emergence increases over time in lamivudine refractory patients. Hepatology 2006;44:Suppl 1:229A-230A. abstract.

Copyright (c) 2007 Massachusetts Medical Society.

PERSONAL ARCHIVES IN THE JOURNAL ONLINE

Individual subscribers can store articles and searches using a feature on the Journal's Web site (www.nejm.org) called "Personal Archive."

Each article and search result links to this feature. Users can create personal folders and move articles into them for convenient retrieval later. 